\title{
16. FLUID EVOLUTION IN OCEANIC CRUSTAL LAYER 2: FLUID INCLUSION EVIDENCE FROM THE SHEETED DIKE COMPLEX, HOLE 504B, COSTA RICA RIFT ${ }^{1}$
}

\author{
Deborah S. Kelley, ${ }^{2}$ David A. Vanko, ${ }^{3}$ and Chifeng Gu${ }^{3}$
}

\begin{abstract}
Fluid inclusions in variably altered diabase recovered from Ocean Drilling Program Legs 137 and 140 at Hole 504B, Costa Rica Rift, exhibit fluid salinities up to 3.7 times that of seawater values (11.7 wt\% $\mathrm{NaCl}$ equivalent) and exhibit uncorrected homogenization temperatures of $125^{\circ} \mathrm{C}$ to $202^{\circ} \mathrm{C}$. The liquid-dominated inclusions commonly are entrapped in zones of secondary plagioclase and may be primary in origin. Fluid salinities are similar to compositions of fluids venting on the seafloor (0.4-7.0 wt $\% \mathrm{NaCl}$ ) and overlap with those measured in metabasalt samples recovered from near the Kane Fracture Zone on the MidAtlantic Ridge and from the Troodos ophiolite. Cyprus. The salinity variations may reflect hydration reactions involving formation of secondary mineral assemblages under rock-dominated conditions, which modify the ionic strength of hydrothermal fluids by consuming or liberating water and chloride ion. Rare $\mathrm{CO}_{2}-\mathrm{CH}_{4}$-bearing inclusions, subjacent to zones where talc after olivine becomes an important secondary mineral phase (1700 mbsf), may have formed due to local interaction of seawater and olivine at low water to rock ratios. Corrected average fluid inclusion homogenization temperatures exhibit a gradient from $159^{\circ} \mathrm{C}$ at a depth of $1370 \mathrm{mbsf}$ to $183^{\circ} \mathrm{C}$ at a depth of $1992 \mathrm{mbsf}$ and are in apparent equilibrium with the present conductive downhole temperatures. These data indicate that fluid inclusions may be used to estimate downhole temperatures if logging data are unavailable. The compositional and thermal evolution of the diabase-hosted fluids may reflect late-stage, off-axis circulation and conductive heating of compositionally modified seawater in the sheeted dike complex at Hole 504B.
\end{abstract}

\section{INTRODUCTION}

The thermal and compositional evolution of seawater as it circulates in oceanic crustal Layer 2 is not well constrained as previous studies have generally involved analyses of fluids hosted in plutonic samples recovered from fracture-zone-related environments and from ophiolites. Analyses of fluid inclusions associated with these hightemperature plutonic systems indicate a bipartite fluid evolution from magmatic conditions involving fluids with salinities of 30-50 wt\% $\mathrm{NaCl}$ equivalent and which contain variable amounts of $\mathrm{CO}_{2}$, to fluids with seawater-like salinities at temperatures of $300^{\circ}-400^{\circ} \mathrm{C}$ (Kelley and Delaney, 1987; Nehlig and Juteau, 1988; Vanko; 1988; Vanko et al., 1992; Kelley et al., 1992; Kelley et al., in press). The lowtemperature fluids, which commonly exhibit salinities of $10 \%$ to $200 \%$ of seawater values, compositionally overlap with fluids exiting submarine hydrothermal vents. Although such studies provide information on the deep and shallow components of submarine hydrothermal systems, little is know about the nature of diabase-hosted fluids and the evolution of these fluids as a crustal sequence is transported away from the spreading environment.

Variably altered diabase samples recovered from the sheeted dike complex of Hole 504B provide our most complete reference section of in-situ oceanic crustal Layer 2. Microthermometric analyses of fluids entrapped in samples representing a $600-\mathrm{m}$ section of the complex indicate that fluid circulation involved compositionally modified seawater with equivalent fluid salinities up to 3.7 times that of seawater values, at temperatures reaching 190 ÉC. The entrapped fluids are not in thermal equilibrium with greenschist alteration mineral assemblages, which are common throughout the diabase sequence, but are in thermal equilibrium with the present conductive downhole temperatures. These data indicate that the inclusions may record off-axis passive circulation of compositionally evolved fluids, associated with conductive heating of the crust.

'Erzinger, J., Becker, K., Dick. H.J.B., and Stokking, L.B. (Eds.), 1995. Proc. ODP, Sci. Results, 137/140: College Station. TX (Ocean Drilling Program).

${ }^{2}$ School of Oceanography, University of Washington, Seattle, WA 98195, U.S.A.

${ }^{3}$ Department of Geology, Georgia State University, Atlanta, GA 30303, U.S.A.

\section{HOLE 504B}

Ocean Drilling Program Hole 504B, located $200 \mathrm{~km}$ south of the Costa Rica Rift, extends to a depth of $2 \mathrm{~km}$ into 5.9-m.y.-old crust formed in an intermediate- to fast-spreading ridge environment (Fig. 1). Relatively smooth basement topography, coupled with a thick sediment cover in this area, results in an elevated geothermal gradient and projected bottom-hole temperatures of approximately $192^{\circ} \mathrm{C}$ (Shipboard Scientific Party, 1992). The hole, which penetrates $274.5 \mathrm{~m}$ of sediments, $571.5 \mathrm{~m}$ of pillow lavas and minor flows, a 209-m transition zone of mixed pillow and massive lavas and dikes, and $945.5 \mathrm{~m}$ of dikes, is believed to penetrate into crustal rocks near the Layer $2 / 3$ boundary (Dick, Erzinger, Stokking, et al., 1992).

\section{Legs 137 and 140}

Drilling during Legs 137 and 140 resulted in deepening of the hole $439 \mathrm{~m}$, with an average recovery of $13 \%-16 \%$. The basaltic rocks recovered are geochemically homogeneous olivine to slightly quartz normative tholeiites and include aphyric and sparsely phyric to moderately phyric basalts, which contain variable amounts of olivine, clinopyroxene, and plagioclase as phenocryst phases. Chilled dike contacts are rare, and evidence for pervasive deformation is lacking. Grain size of the diabase is generally coarser than for samples recovered on previous legs. Sequences of grain size coarsening and fining downhole are believed to reflect multiple dike injections within the complex (Umino, this volume).

Hydrothermal alteration in the diabase suite is variable and complex, involving multiple hydrothermal pulses (Alt et al., 1986, 1989; Shipboard Scientific Party, 1992). Rocks generally exhibit 10\%-20\% static background alteration; however, in localized patches and in alteration halos adjacent to veins, replacement by secondary phases is $70 \%-90 \%$ (Fig. 2). The initial onset of fluid penetration into the lower sheeted dike complex was responsible for the growth of hydrothermal clinopyroxene and, more commonly, the development of centimeterscale fracture halos characterized by hydrothermal calcic plagioclase (to $\mathrm{An}_{93}$, Table 1) and aluminous amphibole (see Laverne et al., this volume). The calcic secondary plagioclase, which contains abundant 


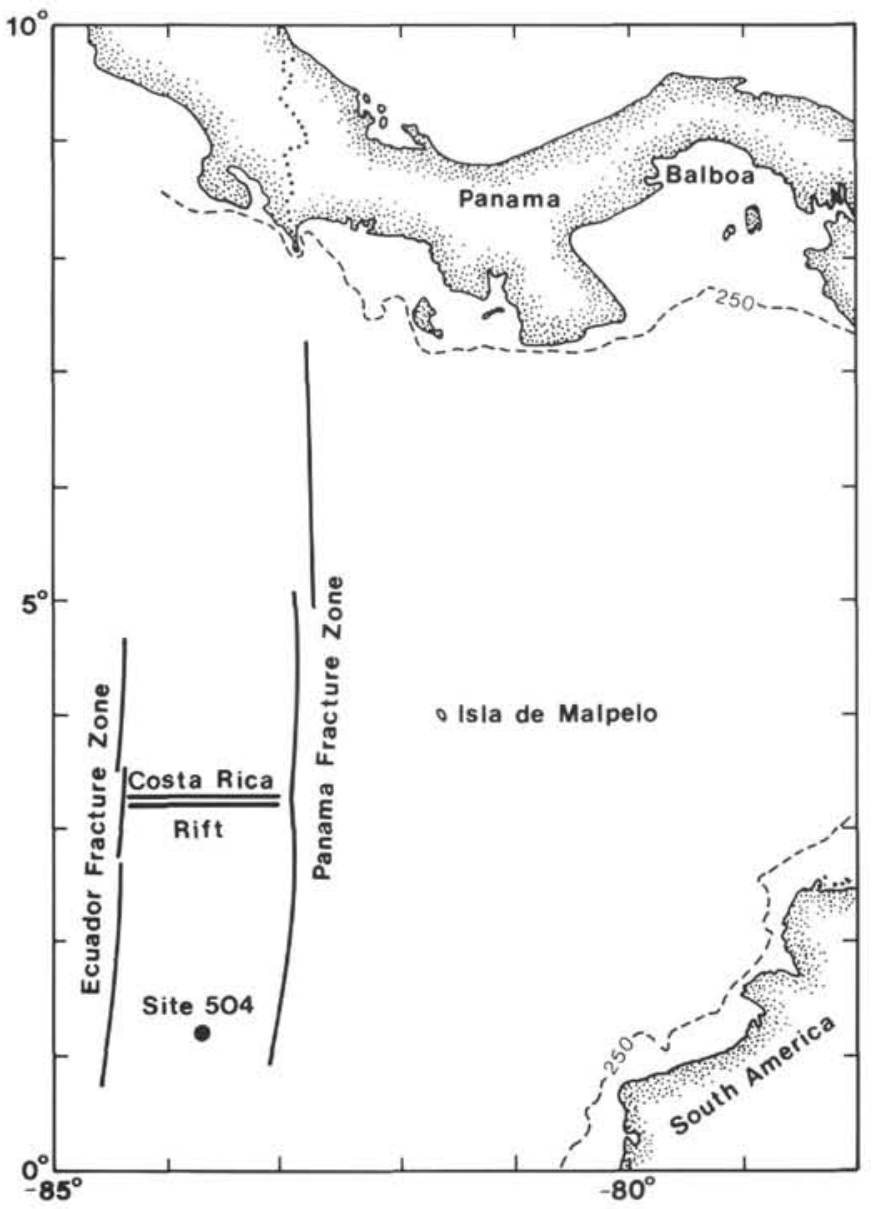

Figure 1. Location of Site 504, drilled approximately $200 \mathrm{~km}$ south of the Costa Rica Rift in 5.9-m.y.-old crust.

fluid inclusions, is commonly cut by a later generation of veins containing sodic plagioclase (also containing fluid inclusions) and zeolite.

The major stage of fluid penetration into the sheeted dike complex is marked by formation of matrix and vein-filling greenschist mineral assemblages (actinolite and actinolite + chlorite epidote). Alteration patches, up to several centimeters across and forming up to $40 \%$ of individual cores, and alteration halos around veins involve extensive replacement of primary minerals by actinolite, chlorite, sodic plagioclase, titanite, and trace epidote, anhydrite, and prehnite. The patches commonly rim actinolite and actinolite + chlorite amygdules; however, in many cases amygdules in the cores of these patches are absent. The origin of the amygdules is unclear, but they may reflect infilling of zones of enhanced porosity by secondary phases, or localized replacement of glassy or fine-grained groundmass. Flow of fluids in these zones was facilitated by flow along grain boundaries and by diffusion.

Static background alteration is dominated by actinolite after clinopyroxene, which locally may form up to about 40 modal $\%$ of the rocks. Olivine alteration is highly variable on a local scale, involving complex and heterogeneous coronitic replacement. Secondary minerals after olivine commonly include varying amounts of chlorite, talc, talc-smectite, actinolite, mixed-layer clays, magnetite, hematite, pyrite, chalcopyrite, and rare quartz. Olivine is commonly pervasively altered; however, in the lower $350 \mathrm{~m}$, relict olivine is present locally. The heterogeneous zonation of secondary minerals after olivine is believed to reflect variations in temperature, kinetic effects, and local variation in water to rock ratios. Plagioclase alteration is patchy and

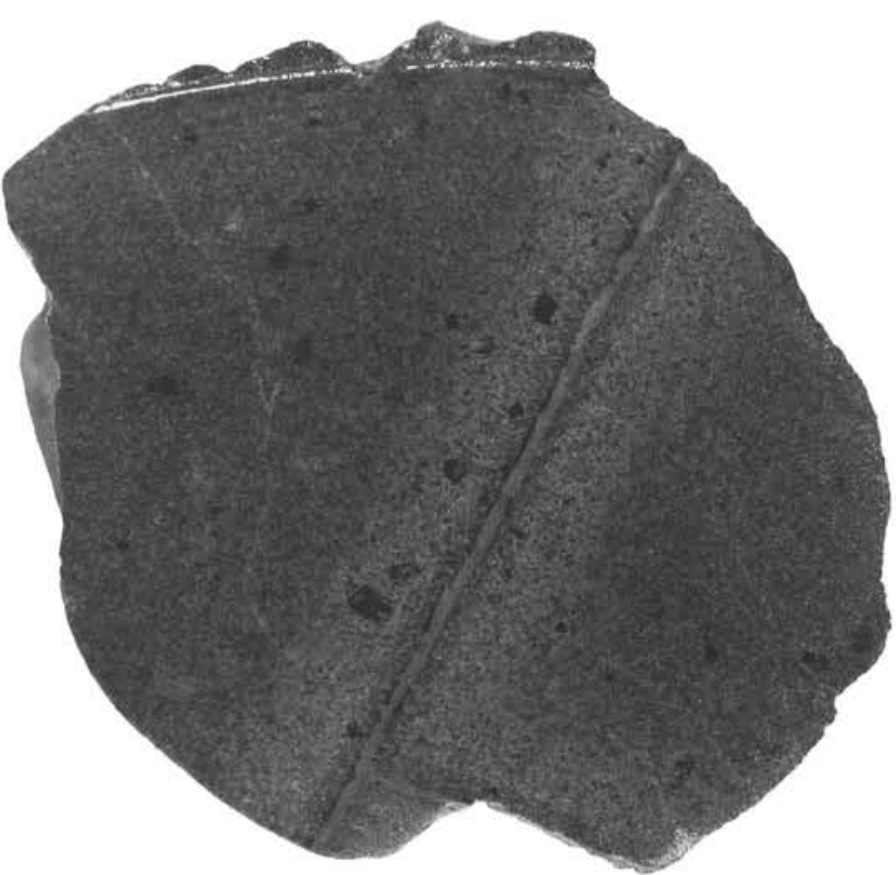

Figure 2. Altered diabase sample with actinolite veins meeting at $90^{\circ} \mathrm{C}$, with well-developed compound halos. Plagioclase-hosted fluid inclusions in halo and background matrix minerals do not exhibit variations in homogenization temperatures or fluid salinities. Primary mineral phases in the halos are extensively recrystallized $(40 \%-90 \%)$, with actinolite, chlorite, secondary plagioclase, and titanite as common alteration phases. Sample 140-504B-197R-1 (Piece 22, 100-104 cm).

Table 1. Plagioclase analyses from Leg 140 diabase.

\begin{tabular}{|c|c|c|c|c|c|c|}
\hline \multirow{2}{*}{$\begin{array}{l}\text { Sample } \\
\text { Oxides }\end{array}$} & \multicolumn{3}{|c|}{$\begin{array}{c}\text { 140-504B-205R-1, } 4-8 \mathrm{~cm} \\
\text { Piece I }\end{array}$} & \multicolumn{3}{|c|}{$\begin{array}{c}\text { 140-504B-22। R-1, } 23-27 \mathrm{~cm} \\
\text { Piece } 8\end{array}$} \\
\hline & $\begin{array}{c}\text { Primary } \\
\text { lath }\end{array}$ & $\begin{array}{c}\text { Early } 2 \\
\text { rim }^{3}\end{array}$ & $\begin{array}{l}\text { Late } 2 \\
\text { veinlet }^{\mathrm{n}}\end{array}$ & $\begin{array}{c}\text { Primary } \\
\text { lath }\end{array}$ & $\begin{array}{c}\text { Early } 2 \\
\text { rim }^{3}\end{array}$ & $\begin{array}{c}\text { Late } 2 \\
\text { veinlet" }\end{array}$ \\
\hline $\mathrm{SiO}_{2}$ & 49.63 & 45.10 & 66.10 & 48.15 & 46.35 & 64.76 \\
\hline $\mathrm{TiO}_{2}^{-}$ & 0.06 & 0.00 & 0.02 & 0.03 & 0.00 & 0.00 \\
\hline $\mathrm{Al}_{2} \mathrm{O}_{3}$ & 31.29 & 35.21 & 22.20 & 32.00 & 34.96 & 22.50 \\
\hline $\mathrm{FeO}$ & 0.52 & 0.15 & 0.20 & 0.36 & 0.23 & 0.16 \\
\hline $\mathrm{MnO}$ & 0.00 & 0.00 & 0.00 & 0.01 & 0.01 & 0.00 \\
\hline $\mathrm{MgO}$ & 0.26 & 0.02 & 0.0 & 0.2 & 0.00 & 0.00 \\
\hline $\mathrm{CaO}$ & 15.27 & 18.92 & 2.2 & 15.5 & 17.59 & 2.95 \\
\hline $\mathrm{SrO}$ & 0.17 & 0.14 & 0.20 & & 0.1 & 0.1 \\
\hline $\mathrm{Na}_{2} \mathrm{O}$ & 2.92 & 0.88 & 10.43 & 2.66 & 1.62 & 9.89 \\
\hline $\mathrm{K}_{2} \mathrm{O}$ & 0.00 & 0.00 & 0.02 & 0.00 & 0.00 & 0.00 \\
\hline $\mathrm{BaOO}$ & 0.00 & 0.00 & 0.04 & na & na & na \\
\hline $\mathrm{CuO}$ & 0.00 & 0.06 & 0.00 & na & na & na \\
\hline Total 1 & 100.12 & 100.48 & 101.50 & 99.18 & 100.94 & 100.39 \\
\hline \multicolumn{7}{|c|}{ Ions based on 8 oxygens } \\
\hline $\mathrm{Si}$ & 2.2714 & 2.0751 & 2.8682 & 2.2269 & 2.1159 & 2.8424 \\
\hline $\mathrm{Ti}$ & 0.0021 & 0.0000 & 0.0 & 0.0010 & 0.00 & 0.0000 \\
\hline & 1.688 & 1.9099 & 1.1. & 8 & 1.8 & \\
\hline & 0.0199 & 0.005 & & 0.0 & 0.00 & 0.0059 \\
\hline $\mathrm{Mn}$ & 0.0000 & 0.0000 & 0.0000 & 0.0004 & 0.0004 & 0.0000 \\
\hline $\mathrm{Mg}$ & 0.0177 & 0.0014 & 0.0000 & 0.0200 & 0.0000 & 0.0000 \\
\hline $\mathrm{Ca}$ & 0.7488 & 0.9328 & 0.1065 & 0.7691 & 0.8604 & 0.1387 \\
\hline $\mathrm{Sr}^{\prime}$ & 0.0045 & 0.0037 & 0.0050 & 0.0043 & 0,0048 & 0.0033 \\
\hline $\mathrm{Na}$ & 0.2591 & 0.0785 & 0.8776 & 0.2385 & 0.14 & 0.84 \\
\hline K & 0.0000 & 0.0000 & 0.0011 & 0.0000 & 0.0000 & 0.0000 \\
\hline $\mathrm{Ba}$ & 0.0000 & 0.0000 & 0.0007 & na & na & na \\
\hline $\mathrm{Cu}$ & 0.0000 & 0.0021 & 0.0000 & na & na & na \\
\hline Total & 5.0119 & 5.0092 & & 5.0190 & 5.0151 & 4.9963 \\
\hline An $\%$ & 74.3 & 92.2 & 10.8 & 76.3 & 85.7 & 14.2 \\
\hline
\end{tabular}

Notes: na $=$ not analyzed: $\mathrm{An} \%=$ anorthite percent. 2 indicates secondary plagioclase. 
involves replacement by chlorite and secondary plagioclase. Alteration commonly occurs along grain boundaries and fractures, and inclusionrich zones of secondary plagioclase are common (Fig. 3). Alteration intensity decreases with depth. Trace amounts of prehnite and anhydrite occur below $1790 \mathrm{~m}$, and fine granular epidote after plagioclase is present below $1814 \mathrm{~m}$.

The presence of amphibole after clinopyroxene, amphibole infilling crack networks, and calcic plagioclase with amphibole in vein halos, indicates that migration of seawater in the diabase sequence occurred at temperatures $>300^{\circ} \mathrm{C}$ and is believed to reflect circulation of fluids near the ridge axis. In the lower 300 to $350 \mathrm{~m}$ of the dike sequence, an increase of actinolite and amphibole after clinopyroxene, preservation of relict olivine, and a decrease in plagioclase alteration suggest increasing alteration temperatures with depth and an associated local decrease in fluid access and water to rock ratios. A strong zinc depletion in the lower $350 \mathrm{~m}$ of the core may represent a reaction zone similar to that observed near the basal section of sheeted dikes in ophiolites (Richardson et al., 1987; Schiffman and Smith, 1988; Schiffman et al., 1990) and a source for trace metals concentrated in upwardly migrating fluids. Local replacement of plagioclase by anhydrite in Leg 140 samples, and rare occurrences of anhydrite in pseudomorphs after olivine and in veins, may reflect a renewed pulse of seawater into the sheeted dike complex at temperatures of $150^{\circ} \mathrm{C}$, as the crust moved away from the spreading axis. Rare zeolites (primarily laumontite), which form interstitial to chlorite, epidote, and actinolite, may indicate continued off-axis circulation of fluids at temperatures $<150^{\circ} \mathrm{C}$.

In the following sections, we present the results of fluid inclusion analyses on a representative suite of the variably altered and veined samples recovered during Legs 137 and 140, and discuss a model for fluid evolution in the sheeted dike complex at Hole 504B.

\section{FLUID INCLUSIONS}

\section{Methods}

Microthermometric analyses of fluid inclusions were conducted on Fluid Inc. adapted USGS gas-flow heating and freezing stages located at Woods Hole Oceanographic Institution and Georgia State University, according to the procedures outlined by Roedder (1984). Replicate homogenization and freezing measurements were conducted on indi- vidual inclusions to obtain corresponding homogenization temperatures and fluid salinities. Homogenization temperatures were measured during progressive heating of the sample to avoid decrepitation and phase changes associated with stretching and leaking. As inclusions in the Hole 504B samples were relatively sparse, reported analyses generally represent single inclusion measurements. In rare samples in which inclusions were abundant, reported analyses represent measurement of a subpopulation of 2 to 3 individual inclusions along an array of inclusions, or of a cluster of primary inclusions in which all inclusions displayed consistent phase ratios and behaved similarly. Thermocouple accuracy was evaluated by measuring phase transitions of synthetic fluid inclusions at $-56.6^{\circ} \mathrm{C}, 0.0^{\circ} \mathrm{C}$, and $+374^{\circ} \mathrm{C}$. All analyses were reproducible to within $0.1^{\circ} \mathrm{C}$. Fluid salinities were obtained using the equations of Potter et al. (1977, 1978).

\section{FLUID INCLUSION TYPES AND RESULTS}

Fluid inclusion types were described and classified petrographically at room temperature before microthermometric analyses. Aqueous fluid inclusions are common to rare in plagioclase in the variably altered diabase recovered from Hole 504B and are rare in epidote and quartz. The diabase-hosted inclusions are generally small to moderate in size $(7-15 \mu \mathrm{m})$; however, rare inclusions are up to $50-70 \mu \mathrm{m}$. Microthermometric analyses of large inclusions were avoided as they commonly decrepitated or leaked during heating and freezing cycles. Compositional and thermal analyses of the entrapped fluids, and information concerning inclusion occurrence and sample depths are summarized in Table 2. Three types of fluid inclusions are recognized at room temperature within the diabase.

\section{Type 1: Liquid-dominated, Low-salinity Inclusions}

In plagioclase, liquid-dominated inclusions commonly occur as irregularly shaped inclusions within rims of secondary calcic plagioclase (see Laverne et al., this volume) and within later crosscutting albite veinlets (Fig. 3, Table 1). The inclusions may be primary in origin, though textural evidence is not conclusive. Distinct arrays of secondary fluid inclusions along healed microfractures are moderately rare in plagioclase, as are primary and secondary, liquid-dominated inclusions in epidote and quartz. Plagioclase-hosted inclusions homog-

Table 2. Fluid inclusion analyses, sheeted dike complex, Hole 504B, Legs 137 and 140.

\begin{tabular}{|c|c|c|c|c|c|c|c|c|c|c|}
\hline Sample & Piece & $\begin{array}{l}\text { Depth } \\
\text { (mbsf) }\end{array}$ & $\begin{array}{c}\text { Th }\left({ }^{\circ} \mathrm{C}\right) \\
(\min -\max )\end{array}$ & Avg (\#) & s.d. & $\begin{array}{l}\text { Th }\left({ }^{\circ} \mathrm{C}\right) \\
\text { corrected }\end{array}$ & $\begin{array}{c}\mathrm{NaCl}(\mathrm{wt} \%) \\
(\min -\max )\end{array}$ & Avg (\#) & s.d. & Comments \\
\hline $173 R-1,60-63$ & 7 & 1571 & $148-168$ & $157(4)$ & 8.6 & 184 & $3.1-4.5$ & $3.6(4)$ & 0.6 & Alteration halo near vug \\
\hline $176 \mathrm{R}-1,15-18$ & 3 & 1596 & 127 & $127(1)$ & & 151 & 3.2 & $3.2(1)$ & & Alteration halo adjacent to vein \\
\hline $181 \mathrm{M}-2.15-16$ & 2 & 1621 & $141-163$ & $150(7)$ & 8.3 & 176 & $1.7-5.1$ & $3.2(8)$ & 1.2 & Alteration adjacent to vein \\
\hline $186 \mathrm{R}-2,21-25$ & 7 & 1631 & $125-148$ & $138(7)$ & 9.6 & 163 & $3.5-4.8$ & $3.8(6)$ & 0.6 & Alteration halo adjacent to vein \\
\hline $194 \mathrm{R}-1,120-123$ & 23 & 1689 & $124-142$ & $133(2)$ & 12.7 & 158 & $3.2-4.0$ & $3.6(2)$ & 0.6 & Alteration adjacent to vein \\
\hline $197 \mathrm{R}-1,73-76$ & $16^{\mathrm{a}}$ & 1703 & $136-166$ & $148(16)$ & 6.4 & 174 & $2.2-11.7$ & $4.1(16)$ & 2.1 & Alteration halo adjacent to vein \\
\hline $200 \mathrm{R}-2,112-115$ & 17 & 1733 & $151-160$ & $157(6)$ & 3.8 & 185 & $0.0-5.8$ & $2.1(7)$ & 2.3 & Alteration adjacent to vein \\
\hline $201 \mathrm{R}-1,19-22$ & 5 & 1745 & 142 & $142(1)$ & & 168 & 6.9 & $6.9(1)$ & & Background matrix alteration \\
\hline $205 \mathrm{R}-1,100-102$ & 24 & 1760 & $140-161$ & $148(12)$ & 7.6 & 174 & $0.5-4.0$ & $2.4(14)$ & 1.0 & Alteration halo adjacent to vein \\
\hline $208 \mathrm{R}-3,8-10$ & 1 & 1788 & $145-170$ & $154(7)$ & 8.8 & 181 & $2.0-7.5$ & $3.5(15)$ & 1.3 & Vug-hosted alteration \\
\hline $209 R-2,105-108$ & 17 & 1790 & $146-179$ & $152(25)$ & 7.2 & 179 & $3.2-4.6$ & $3.6(25)$ & 0.5 & Vug and alteration halo \\
\hline $210 \mathrm{R}-1.68-70$ & 10 & 1796 & $139-202$ & $162(12)$ & 21.1 & 191 & $1.1-3.7$ & $2.3(13)$ & 1.1 & Alteration adjacent to vein \\
\hline $213 \mathrm{R}-1,85-89$ & 22 & 1813 & $143-155$ & $147(28)$ & 2.5 & 174 & $2.9-4.2$ & $3.4(28)$ & 0.4 & Background matrix alteration \\
\hline $214 \mathrm{R}-2,85-88$ & 21 & 1823 & $157-186$ & $171(2)$ & 20.5 & 200 & 3.5 & $3.5(1)$ & & Vug-hosted alteration \\
\hline $216 \mathrm{R}-1,30-34$ & 8 & 1831 & $144-164$ & $150(4)$ & 9.1 & 178 & $2.9-4.8$ & 3.7 (7) & 0.6 & Alteration adjacent to vein \\
\hline $216 \mathrm{R}-1,59-63$ & 13 & 1834 & $140-166$ & $146(16)$ & 5.8 & 173 & $2.9-4.0$ & $3.5(6)$ & 0.4 & Quartz vein \\
\hline $221 \mathrm{R}-1,24-29$ & 8 & 1878 & $133-152$ & $145(11)$ & 6.5 & 172 & $2.4-3.7$ & $3.2(11)$ & 0.6 & Background matrix alteration \\
\hline $226 \mathrm{R}-1,45-48$ & 10 & 1920 & $144-166$ & 154 (19) & 6.5 & 182 & $2.4-5.3$ & $3.5(19)$ & 0.7 & Vug-hosted alteration \\
\hline $228 \mathrm{R}-1,56-60$ & 13 & 1941 & $144-188$ & $158(14)$ & 14.0 & 186 & $0.5-5.1$ & $3.3(15)$ & 1.6 & Alteration adjacent to vein \\
\hline $237 \mathrm{R}-1,8-10$ & 2 & 1984 & $150-176$ & $162(26)$ & 6.5 & 191 & $1.2-5.4$ & $3.4(26)$ & 0.7 & Vug-hosted alteration \\
\hline $237 \mathrm{R}-1,22-26$ & 7 & 1992 & $143-175$ & $154(16)$ & 10.6 & 183 & $1.4-4.0$ & $3.1(21)$ & 0.7 & Alteration adjacent to vein \\
\hline
\end{tabular}

Notes: Sample numbers refer to core, section, and interval $($ in $\mathrm{cm}$ ); mbsf $=$ meters below seafloor expanded depth; Th $=$ homogenization temperature-minimum and maximum; Avg $(\#)=$ average homogenization temperature and number of inclusions measured; $\mathrm{s} . \mathrm{d} .=\mathrm{standard}$ deviation: Th corrected $=$ homogenization temperature corrected for hydrostatic pressure effects: $\mathrm{NaCl}($ wt $\%)=$ weight percent equivalent fluid salinity.

aSample also contains $\mathrm{CO}_{2}-\mathrm{CH}_{4}$-bearing inclusions that exhibit freezing temperatures of $-135^{\circ}$ to $-159^{\circ} \mathrm{C}, \mathrm{CO}_{2}-\mathrm{CH}_{4}$ solid melting temperatures of $-97^{\circ}$ to $-99^{\circ} \mathrm{C}$, and homogenization temperatures of bubbles that form on freezing of $-5^{\circ}$ to $+23^{\circ} \mathrm{C}$. 


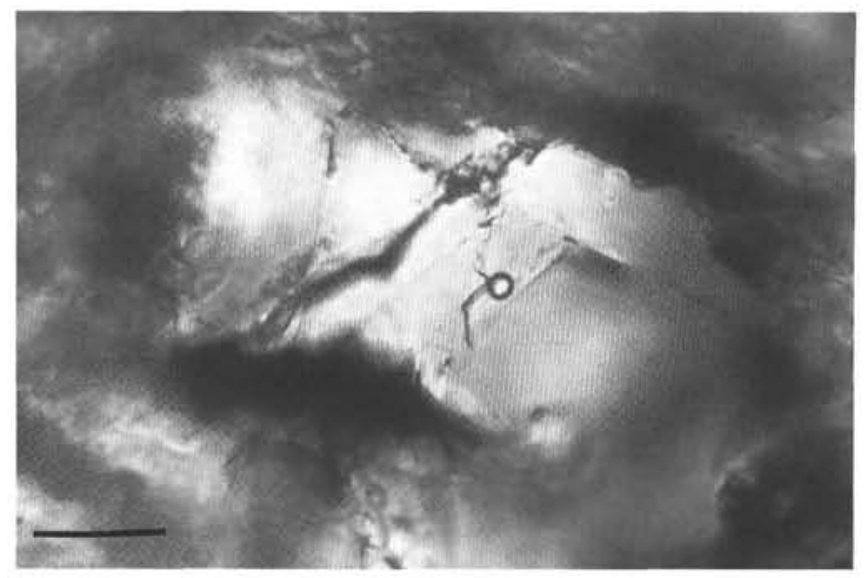

Figure 3. Photomicrograph of Type 1, liquid-dominated inclusion in zone of altered plagioclase (Sample 140-504B-213R-1, Piece 22, 85-89 cm). Inclusions contain a small vapor bubble, rimmed by a low-salinity liquid. Scale bar is equal to $15 \mu \mathrm{m}$.

enize in the liquid phase $[\mathrm{Th} \mathrm{L}+\mathrm{V}(\mathrm{L})]$ at uncorrected temperatures of $124^{\circ}$ to $202^{\circ} \mathrm{C}$ and exhibit melting events at $0.0^{\circ} \mathrm{C}$ to $-8.0^{\circ} \mathrm{C}$, indicating fluid salinities of 0.0 to $11.7 \mathrm{wt} \% \mathrm{NaCl}$ equivalent (Figs. 4 and 5). Average fluid salinities $(3.3 \pm 1.1 \mathrm{wt} \% \mathrm{NaCl}$ equivalent) cluster near seawater values $(3.2 \mathrm{wt} \% \mathrm{NaCl})$. There is no significant difference in homogenization temperatures or in compositions of fluid inclusions in matrix-forming sodic plagioclase and calcic plagioclase in alteration halos associated with veins and amygdules.

Uncommonly, liquid-dominated inclusions exhibit indirect evidence for the presence of dissolved gas and of clathrate formation on cooling. For example, freezing relations for an inclusion in Sample 140-504B-216R-1 (Piece 8, 30-34 cm) are explained by ice melting at $-2.9^{\circ} \mathrm{C}$ and clathrate melting at $-2.1^{\circ} \mathrm{C}$. Reconnaissance crushing stage experiments of two vein-halo samples and one sample of background matrix alteration show that the expansion of vapor bubbles on crushing is common, indicating the presence of compressed gases. Phase changes of some of the inclusions inferred to have salinities highly depleted with respect to seawater values may, thus, reflect clathrate melting events rather than ice melting; therefore, calculated salinities of these inclusions may be erroneously low. Additional crushing experiments and micro-Raman spectroscopic analyses are needed to confirm the presence of volatile phases and to determine compositions of the entrapped volatile species in these inclusions.

Quartz-hosted, liquid-dominated inclusions were measured in one quartz vein (Sample 140-504B-216R-1, Piece 13, 59-63 cm). Inclusions in this sample homogenize in the liquid phase at uncorrected temperatures of $140^{\circ}$ to $146^{\circ} \mathrm{C}$ and exhibit salinities of 2.9 to $4.0 \mathrm{wt} \%$ $\mathrm{NaCl}$ equivalent (Table 2). The quartz-hosted inclusions overlap with respect to temperature and composition with plagioclase-hosted, liquid-dominated inclusions in an adjacent sample (Sample 140-504B216R-1, Piece 8, 30-34 cm) and are similar to other diabase-hosted inclusions (Figs. 4 and 5; Table 2).

\section{Type 2: Liquid-dominated, Vapor-bubble-absent Inclusions}

Liquid-dominated, vapor-bubble-absent inclusions were only observed in Sample 140-504B-197R-1 (Piece 16, 73-76 cm), and inclusion origin could not be determined (Table 2). The irregularly shaped, small-sized inclusions do not exhibit a vapor bubble at room temperature, but nucleate a small bubble on cooling. These inclusions exhibit freezing temperatures of $-135^{\circ}$ to $-159^{\circ} \mathrm{C}$ and exhibit melting temperatures of a solid phase at $-97^{\circ}$ to $-99^{\circ} \mathrm{C}$. Homogenization of the vapor bubbles that formed during cooling occurs at temperatures of $-5^{\circ}$ to $+23^{\circ} \mathrm{C}$. Although clathrate formation was not directly observed, phase

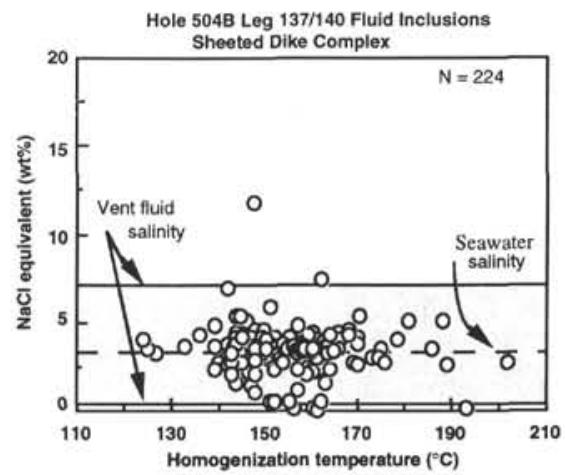

Figure 4. Uncorrected homogenization temperatures and corresponding equivalent fluid salinities for plagioclase-hosted inclusions. Low-salinity, primary(?) and secondary inclusions in secondary plagioclase homogenize in the liquid phase [Th $\mathrm{L}+\mathrm{V}$ (L)] at temperatures of $127^{\circ}$ to $202^{\circ} \mathrm{C}$ and contain equivalent salinities of 0.0 to $11.7 \mathrm{wt} \% \mathrm{NaCl}$. Inclusion salinities are up to 3.7 times that of seawater (dashed line) and generally overlap the field for fluids exiting submarine hydrothermal vents (stippled field). $\mathrm{N}$ denotes number of inclusions measured.

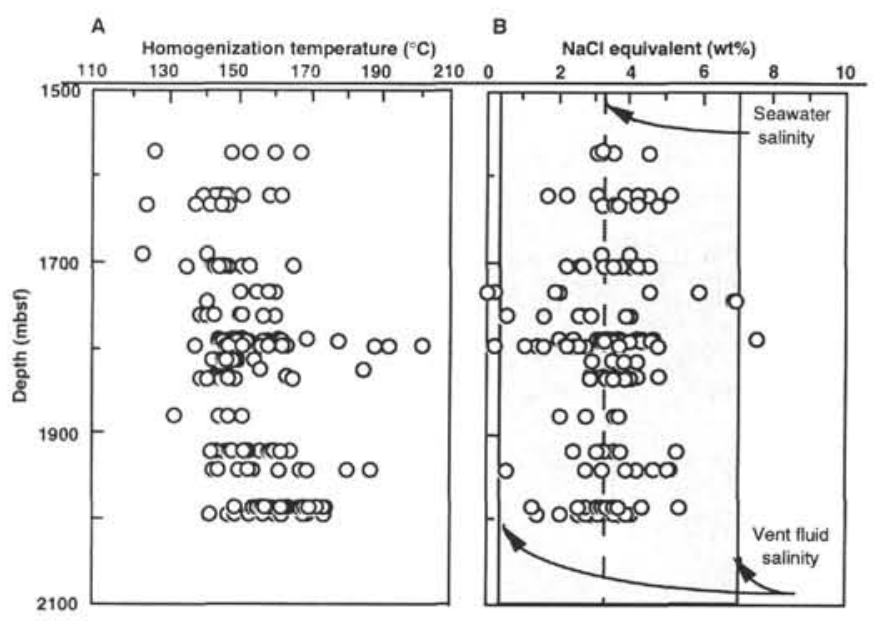

Figure 5. Temperatures of homogenization and fluid salinities for diabasehosted inclusions from Legs 137 and 140. (A) Uncorrected homogenization temperatures of individual inclusions as a function of depth (mbsf). Homogenization temperatures exhibit a gradient from $157^{\circ} \mathrm{C}$ at a depth of $1571 \mathrm{~m}$ to $175^{\circ} \mathrm{C}$ at $1992 \mathrm{~m}$. (B) Fluid salinities are similar to seawater (dashed line) and overlap the field measured for hydrothermal vents (stippled field). There is no apparent variation of salinity with depth.

changes upon cooling and warming strongly suggest that a clathrate of methane and/or carbon-dioxide formed. These phase changes suggest that the inclusions are dominated by $\mathrm{CO}_{2}$ and $\mathrm{CH}_{4}$ (Roedder, 1984); however, micro-Raman spectroscopic analyses are needed to unequivocally identify the gas species.

\section{Type 3: Liquid-dominated, Daughter-mineral-bearing Inclusions}

Liquid-dominated inclusions that contain a birefringent, rounded daughter mineral are rare. Homogenization temperatures and freezing measurements were not conducted on these samples.

\section{TEMPERATURES OF FLUID ENTRAPMENT}

Pressures of entrapment for the liquid-dominated inclusions in samples from Hole 504B are higher than the equilibrium vapor pres- 
sure, and, therefore, a temperature correction was applied to obtain temperatures of fluid entrapment (Roedder, 1984). The difference between homogenization temperatures of inclusions along the liquidvapor curve and the temperatures of entrapment is a function of the entrapment pressure and of fluid composition. Temperature corrections were obtained using the equations of Zhang and Frantz (1987), assuming an average fluid composition of $3.2 \mathrm{wt} \% \mathrm{NaCl}$ equivalent and assuming that hydrostatic pressure conditions apply $(1 \mathrm{MPa} / \mathrm{km}$ $\mathrm{H}_{2} \mathrm{O}$ ). Pressures of entrapment were calculated using the expanded sample recovery depth and an overlying water column of $3460 \mathrm{~m}$. For the most shallow and deepest diabase samples recovered, the temperature corrections range from $24^{\circ} \mathrm{C}$ to $29^{\circ} \mathrm{C}$, respectively (Table 2), indicating average trapping temperatures of $151^{\circ} \mathrm{C}$ to $200^{\circ} \mathrm{C}$.

\section{DISCUSSION}

The magnitude of rock alteration commonly observed in samples recovered from the ocean basins indicates that fluid circulation has a profound impact on crustal evolution. Complex mineral alteration assemblages in rocks recovered from near-ridge and off-axis environments indicate that plutonic and extrusive sequences experience multiple hydrothermal pulses as the rocks cool and are transported away from the zone of crustal accretion (Alt et al., 1989, 1986; Gillis and Thompson, 1993; Gillis et al., in press; Kelley et al., in press). The thermal and compositional character of hydrothermal systems as they evolve from these "active" to "passive" regions of fluid circulation (Lister, 1983) have not been well studied, predominantly due to the inherent difficulty in obtaining suites of deep crustal rocks from offaxis environments. As passive circulation may account for $>80 \%$ of the total seawater flux through the oceanic crust (Fehn and Cathles, 1986), constraining the nature of fluid circulation in the off-axis environment is of primary importance. Hole 504B represents a unique opportunity to evaluate the nature of passively convecting systems in a geologically and geophysically well-characterized sequence of insitu oceanic crust that has been transported $200 \mathrm{~km}$ south of the Costa Rica Rift. In the following discussion, fluid inclusion analyses, alteration mineral assemblages, and logging data are used to provide constraints on the thermal and compositional evolution of circulating fluids in this 5.9-m.y.-old section of oceanic crust.

\section{THERMAL EVOLUTION}

Background static alteration in the diabase sequence is dominated by the formation of actinolite and amphibole after clinopyroxene; actinolite and actinolite chlorite veins are common. The greenschist alteration and vein-filling minerals are believed to reflect the initial major penetration of seawater into the dike complex at temperatures up to $350^{\circ} \mathrm{C}$ during hydrothermal circulation at the ridge axis (Shipboard Scientific Party, 1992). Stockwork and vein-hosted fluid inclusions that occur at 910-928 mbsf and 1369-1388 mbsf, respectively (Fig. 6), exhibit homogenization temperatures $>400^{\circ} \mathrm{C}$ (Honnorez et al., 1985; Schops and Herzig, 1990) and are believed to result from an axial-related, high-temperature event(s) similar to that in the underlying sheeted dike complex. In the diabase suite, however, matrixhosted fluid inclusions do not record this high-temperature hydrothermal episode associated with active circulation.

Average trapping temperatures of diabase-hosted fluid inclusions in secondary plagioclase range from $159^{\circ} \mathrm{C}$ at a depth of $1370 \mathrm{mbsf}$ to $181^{\circ} \mathrm{C}$ at 1992 mbsf (Fig. 7; Table 2). The trapping temperatures, which exhibit a moderate to well-defined gradient downhole, are in apparent equilibrium with present conductive downhole temperatures (Fig. 7) and record significantly lower temperatures than either peak temperatures indicated by the greenschist alteration mineral assemblages and vein-filling minerals, or by fluid inclusions hosted in the mineralized quartz-veins (Fig. 6). The trapping temperatures of the low-temperature inclusions are in the stability range of albite, but are too low to be in equilibrium with formation of calcic plagioclase (Liou

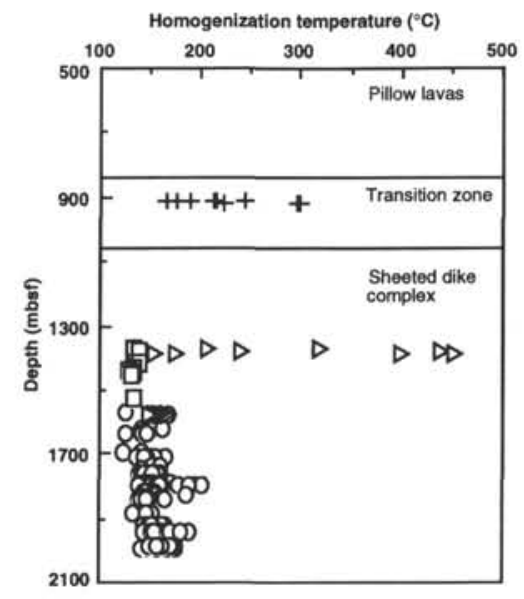

Figure 6. Uncorrected homogenization temperatures of diabase and veinhosted fluid inclusions in Hole 504B. Uncorrected homogenization temperatures for quartz, calcite, and analcite-hosted inclusions in stockwork veins associated with sulfide mineralization in samples recovered during DSDP Leg 83 (crosses; after Honnorez et al., 1985) and quartz-hosted inclusions in quartz-sulfide veins (open triangles; after Schops and Herzig, 1990) commonly exhibit homogenization temperatures significantly higher than those of plagioclase-hosted inclusions in metadiabase (Leg 111, open squares, [Nehlig, 1991]; open circles, this study). The higher-temperature stockwork and vein-hosted inclusions may reflect alteration associated with on-axis circulation of seawater into the transition zone and sheeted dike sequence.

et al., 1974; Spear, 1980; Moody et al., 1983). This may indicate that the inclusions are secondary in origin or may reflect re-equilibration of primary fluid inclusions during leakage associated with the structural weakness of plagioclase at low temperatures. The strong correlation between inclusion trapping temperatures and downhole temperatures provides compelling evidence that the inclusions record off-axis, passive circulation of fluids associated with conductive heating of the crust as it was transported away from the rift environment.

In Hole 504B, borehole temperature measurements and gradient profiles indicate that the thermal regime in the transition zone and sheeted dike section exhibits little temporal variation and is dominated by conductive heat transfer (Becker et al., 1983; Gable et al., 1989; Iturrino et al., this volume). Near the lower pillow lava-sheeted dike transition $(915 \mathrm{mbsf})$, the thermal gradient decreases from $116^{\circ} \mathrm{C} / \mathrm{km}$ in the lower pillow lavas to $61^{\circ} \mathrm{C} / \mathrm{km}$ in the sheeted dikes. This welldefined decrease is accompanied by a proportionally smaller increase in thermal conductivity and an apparent reduction in heat flow from $180 \mathrm{~mW} / \mathrm{m}^{2}$ to $120 \mathrm{~mW} / \mathrm{m}^{2}$, respectively (Gable et al., 1989). A number of hypotheses have been discussed to account for the disparity between shallow and deep values of heat flow at this site; these include thermal disturbances due to drilling, slow convection of fluids in the hole, variations in the thermal conductivity of the rock, and local effects of largescale hydrothermal convection. The well-defined correlation between inclusion trapping temperatures and measured borehole temperatures provides strong evidence that the borehole temperature measurements reflect true formation temperatures and are not a product of borehole phenomena or variable rock conductivity. The fluid inclusion data are consistent with a model involving ongoing slow convection of fluids at depths of $2 \mathrm{~km}$ in the sheeted dike sequence and indicate that fluid transport in this zone may not significantly affect the conductive vertical heat transfer.

\section{FLUID EVOLUTION}

\section{Salinity Variations}

Diabase-hosted fluid inclusions exhibit apparent fluid salinities of 0.0 to $11.7 \mathrm{wt} \% \mathrm{NaCl}$ equivalent and are similar in composition to 


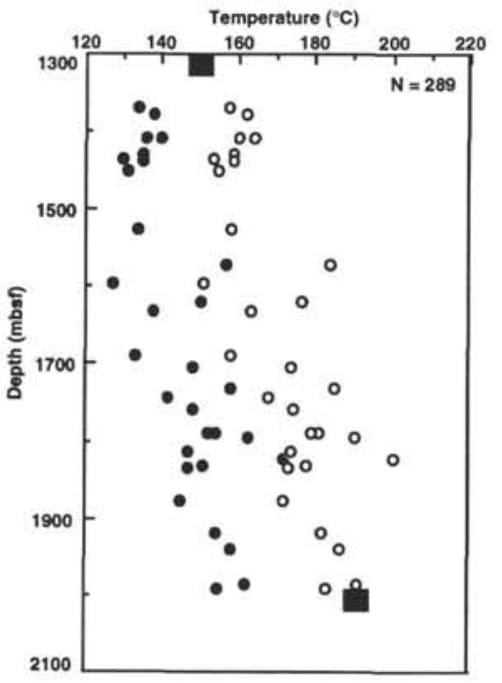

Figure 7. Average uncorrected homogenization temperatures (solid circles) and average pressure-corrected temperatures (open circles) as a function of depth for plagioclase-hosted fluid inclusions in diabase recovered during Legs 111, 137, and 140. Trapping temperatures were calculated assuming an average fluid salinity of $3.2 \mathrm{wt} \% \mathrm{NaCl}$ and that hydrostatic pressures apply. Trapping temperatures exhibit a gradient from $159^{\circ} \mathrm{C}$ at a depth of $1370 \mathrm{mbsf}$ to $181^{\circ} \mathrm{C}$ at $1992 \mathrm{mbsf}$. Corrected homogenization temperatures are in apparent equilibrium with present conductive bottom-hole temperatures (boxes) and may record offaxis, passive circulation of seawater into the sheeted dike sequence as the crust was transported away from the Costa Rica Rift. Homogenization temperatures for inclusions in diabase samples at depths shallower than $1525 \mathrm{~m}$ are after Nehlig (1991). $\mathrm{N}$ denotes number of inclusions measured.

inclusions in the overlying mineralized zones in Hole 504B, to metabasalt-hosted fluid inclusions from the Kane Fracture Zone (MARK) and the Troodos ophiolite, Cyprus, and to fluids exiting submarine hydrothermal vents (Fig. 8). Average fluid salinities (3.3 $\pm 1.1 \mathrm{wt} \% \mathrm{NaCl}$ equivalent) cluster near seawater values $(3.2 \mathrm{wt} \% \mathrm{NaCl})$. As previously discussed, some of the inclusions inferred to contain salinities highly depleted with respect to seawater values may be erroneously low due to the inability to clearly distinguish between ice and clathrate melting events. Several mechanisms have been invoked to account for the range in fluid salinities of vent and deeper-seated fluids, including supercritical phase separation of magmatic and seawater-derived fluids, variable mixing of hydrothermal seawater with phase separated brines and vapors, boiling, and rock hydration.

Formation of brines and vapors by supercritical phase separation of either seawater or magmatic fluids has been well documented in hightemperature hydrothermal systems associated with submarine plutonic environments (Kelley and Delaney, 1987; Vanko, 1988, Kelley et al, 1992; Vanko et al., 1992; Kelley et al., in press). It has been suggested that due to differences in density and wetting characteristics of the brines and vapors generated during phase separation, the two phases may become segregated during migration along microfracture networks (Goldfarb and Delaney, 1988; Fox, 1990). During segregation and migration, preferential accumulation of brines occurs at depth, as the lower-density expanded vapor phase migrates upward. In some axial-related paleohydrothermal systems, such as that at MARK (Delaney et al., 1987), variable mixing of segregated brines with seawater has been shown to be an important mechanism for generating highsalinity fluids. In evolved hydrothermal systems associated with offaxis environments, such as that at Hole 504B, however, it is unlikely that deeply circulating hydrothermal fluids achieve temperatures high enough to undergo phase separation.

Progressive boiling and fractional distillation may also generate fluids with salinities depleted or enriched with respect to seawater

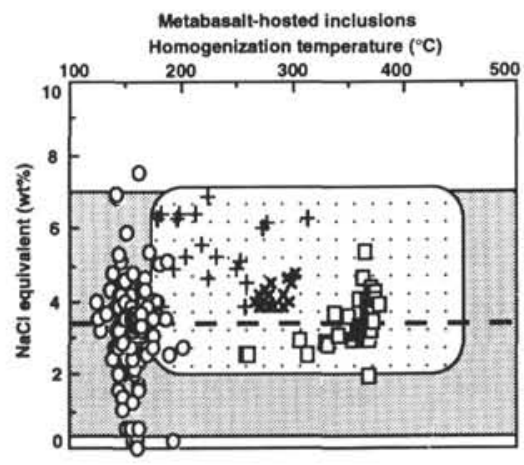

Figure 8. Corresponding uncorrected temperatures of homogenization and equivalent fluid salinities for metabasalt-hosted fluid inclusions in submarine environments. Inclusion salinities are commonly up to 2 times that of seawater (dashed line), and overlap with those measured for submarine hydrothermal vent fluids (dark stippled area). Inclusion homogenization temperatures for samples recovered during Legs 137 and 140 (open circles) are generally lower than plagioclase-hosted inclusions in metabasalt samples from near the eastern intersection of the Mid-Atlantic Ridge and the Kane Fracture Zone (MARK) (light stippled area; crosses and x's; after Kelley et al., in press) and from variably altered diabase samples from the Troodos ophiolite, Cyprus (open squares; after Kelley et al., 1992). Inclusions in stockwork and quartz-sulfide veins recovered during Legs 83 and 111 record temperatures and salinities similar to those exhibited by the MARK and Troodos samples, and may record ridge axis hydrothermal events, whereas plagioclase-hosted inclusions in the 137 and 140 samples record off-axis circulation of seawater. Fluid salinities may result from hydration reactions and formation of secondary mineral phases under rock-dominated conditions.

values (Butterfield et al., 1990). At depth in off-axis environments, however, low temperatures and high pressures constrain migrating fluids to the one-phase region, and it is unlikely that either progressive boiling or distillation associated with passive circulation played a significant role in generating the observed salinity variations. In axialrelated systems actively venting on the seafloor, however, these processes are well documented (Butterfield et al., 1990). Thus, some of the salinity variations observed at Hole 504B may be due to recirculation of previously entrapped phase-separated pore fluids generated during high-temperature circulation of fluids at the ridge axis.

Under rock-dominated conditions, hydration reactions have the potential of modifying the ionic strength of hydrothermal fluids by consuming or liberating water or chloride ion (e.g., Cathles, 1983). The typical diabase from Hole 504B contains $1.5 \mathrm{wt} \% \mathrm{H}_{2} \mathrm{O}$ (reaching a maximum of $3.7 \mathrm{wt} \% \mathrm{H}_{2} \mathrm{O}$ ). If we assume that the average salinity of the circulating fluids is $3.2 \mathrm{wt} \% \mathrm{NaCl}$ (seawater), that chlorine is conserved in the fluid, and that the rock is initially anhydrous, then alteration at a water rock ratio $(\mathrm{w} / \mathrm{r})$ of 0.1 to a diabase with $3.7 \mathrm{wt} \%$ $\mathrm{H}_{2} \mathrm{O}$ results in a pore fluid salinity of $5.1 \mathrm{wt} \% \mathrm{NaCl}$. At very low w/r ratios, hydration reactions may produce highly saline brines; however, the amount of available water becomes limiting. For example, at a w/r ratio of 0.5 , if all the available water is consumed, the maximum rock hydration possible is $4.8 \mathrm{wt} \% \mathrm{H}_{2} \mathrm{O}$. To achieve $\mathrm{H}_{2} \mathrm{O}$ contents of $3.7 \mathrm{wt} \%$, w/r ratios must be no less than 0.04 . In intensely altered zones such as the halos associated with veins and amygdules, in which actinolite and chlorite are modally important phases, hydration reactions may have played an important role in modifying fluid salinities. For this process to be viable, hydration reactions associated with amphibole formation require that fluid salinities were obtained in the near axis environment. It may be that during repeated hydrothermal events significant "reworking" of pore fluids occurs, and that pore fluid salinities are progressively depleted or enriched during these recycling events. 


\section{$\mathrm{CH}_{4}$ - and $\mathrm{CO}_{2}$-bearing Fluids}

The depressed freezing temperatures and first ice melting temperatures of the vapor-bubble-absent inclusions provide strong evidence that the entrapped fluids contain significant amounts of $\mathrm{CH}_{4}$ and $\mathrm{CO}_{2}$. Although $\mathrm{CH}_{4}$ and $\mathrm{CO}_{2}$ are important components of volatiles detected in mid-ocean-ridge glasses (Delaney et al., 1978; Dixon et al., 1988; Javoy and Pineau, 1991) and of hydrothermal fluids venting on the seafloor (Lilley et al., 1983; Welhan, 1988; Charlou et al., 1992; Lilley et al., 1993), only rarely have they been found in deeper crustal rocks (Vanko and Stakes, 1991; Vanko et al., 1992; Kelley et al., in press; Kelley and Frantz, unpubl. data). $\mathrm{CH}_{4}$ and $\mathrm{CH}_{4}-\mathrm{CO}_{2}$-rich fluid inclusions are common to rare, respectively, in the $436 \mathrm{~m}$ section of gabbros recovered from Hole 735B at the Southwest Indian Ridge (Vanko and Stakes, 1991; Kelley and Frantz, unpubl. data), and $\mathrm{CH}_{4}$-rich silicate-bearing inclusions and $\mathrm{CO}_{2}-\mathrm{H}_{2} \mathrm{O}$-rich magmatic inclusions have been found in gabbros recovered from the MARK area on the Mid-Atlantic Ridge (Kelley et al., in press).

Methane and carbon dioxide-bearing fluids have not been previously found in Layer 2 of the oceanic crust, and their origin is not well known. Under rock-dominated conditions, such as those implied by the secondary mineral assemblages at Hole 504B, reduction of seawater carbonate by reaction with olivine and other mafic phases may have played an important role in methane generation (Vanko and Stakes, 1991). Specifically, alteration of olivine to magnetite and talc-bearing assemblages may produce significant $\mathrm{H}_{2}$ (Alt and Anderson, 1991), which may react with seawater carbonate to generate methane. Talc becomes an important secondary mineral phase after olivine in a zone from $1710-1740 \mathrm{~m}$ in Hole 504B, which is just below where the $\mathrm{CH}_{4^{-}}$ $\mathrm{CO}_{2}$-rich fluids are observed $(1703 \mathrm{~m})$. Perhaps in this zone local interaction of seawater with olivine played a significant role in generating the $\mathrm{CH}_{4}-\mathrm{CO}_{2}$-rich fluids.

$\mathrm{CO}_{2}-\mathrm{H}_{2} \mathrm{O}$-rich fluids are not uncommon in gabbros from midocean-ridge environments (Vanko et al., 1992; Kelley et al., in press; Kelley and Frantz, unpubl. data) and methane may form as a result of high-temperature reaction of these fluids with olivine and/or other mafic minerals. As Hole 504B is believed to penetrate close to the Layer $2 / 3$ boundary, the $\mathrm{CH}_{4}$ - $\mathrm{CO}_{2}$-rich inclusions may have entrapped upwardly migrating fluids that originated in underlying gabbros. The occurrence of methane and carbon dioxide-bearing fluids in diabase from Hole 504B, as well as in gabbros from the Kane Fracture Zone and the Southwest Indian Ridge, suggests that these fluids may be a significant source for these volatile species in submarine hydrothermal systems venting on the seafloor.

\section{CONCLUSIONS}

Alteration mineralogy and fluid inclusions hosted in the sheeted dike complex at Hole 504B are the product of a complex history involving multiple hydrothermal pulses under changing magmatic and tectonic conditions. Microthermometric analyses of primary and secondary fluid inclusions in variably altered diabase, representing a $600 \mathrm{~m}$ section of the complex, indicate that fluid circulation involved compositionally modified seawater having equivalent fluid salinities of almost fresh water, to up to 3.7 times that of seawater values. The variations may reflect the progressive depletion or enrichment in pore fluid salinities during hydration reactions at low water to rock ratios and the formation of secondary mineral phases. Rare $\mathrm{CH}_{4}-\mathrm{CO}_{2}$-rich inclusions subjacent to zones where talc after olivine becomes an important secondary mineral phase may have formed due to local interaction of seawater and olivine under rock-dominated conditions. Trapping temperatures of the secondary plagioclase-hosted inclusions, which range from $150^{\circ} \mathrm{C}$ at a depth of $1370 \mathrm{~m}$ to $181^{\circ} \mathrm{C}$ at $1992 \mathrm{~m}$, are in thermal equilibrium with present conductive downhole temperatures, and record significantly lower temperatures than peak temperatures indicated by greenschist alteration mineral assemblages. The inclusions may record off-axis, passive circulation of composi- tionally evolved fluids, associated with conductive heating of the crust as it was transported away from the rift environment. The strong correlation between fluid inclusion trapping temperatures and present conductive downhole temperatures confirms that borehole temperature measurements reflect formation conditions, and indicates that inclusions may provide a powerful tool to estimate downhole temperatures if logging data are unavailable.

\section{ACKNOWLEDGMENTS}

This work benefitted from discussions with Peter Saccocia and Kathy Gillis. Special thanks to David Mogk and James Bischoff for their constructive reviews of the manuscript. This work was supported by grants from JOI/USSAC through the Texas A\&M Research Foundation. Contribution 1972, School of Oceanography, University of Washington.

\section{REFERENCES*}

Alt, J.C., and Anderson, T.F., 1991. Mineralogy and isotopic composition of sulfur in layer 3 gabbros from the Indian Ocean, Hole 735B. In Von Herzen, R.P., Robinson, P.T., et al., Proc. ODP, Sci. Results, 118: College Station, TX (Ocean Drilling Program), 113-126.

Alt, J.C., Anderson, T.F., Bonnell, L., and Muehlenbachs, K., 1989. Mineralogy, chemistry, and stable isotopic compositions of hydrothermally altered sheeted dikes: ODP Hole 504B, Leg 111. In Becker, K., Sakai, H., et al., Proc. ODP, Sci. Results, 111: College Station, TX (Ocean Drilling Program), $27-40$.

Alt, J.C., Honnorez, J., Laverne, C., and Emmermann, R., 1986. Hydrothermal alteration of a $1 \mathrm{~km}$ section through the upper oceanic crust, Deep Sea Drilling Project Hole 504B: mineralogy, chemistry, and evolution of seawater-basalt interactions. J. Geophys. Res., 91:10309-10335.

Becker, K., Langseth, M.G., Von Herzen, R.P., and Anderson, R.N., 1983. Deep crustal geothermal measurements, Hole 504B, Costa Rica Rift. J. Geophys. Res., 88:3447-3457.

Butterfield, D.A., Massoth, G.J., McDuff, R.E., Lupton, J.E., and Lilley, M.D., 1990. Geochemistry of hydrothermal fluids from Axial Seamount Hydrothermal Emissions Study vent field, Juan de Fuca: subseafloor boiling and subsequent fluid-rock interaction. J. Geophys. Res., 95:12895-12921.

Cathles, L.M., 1983. An analysis of the hydrothermal system responsible for massive sulfide deposition in the Hokuroku Basin of Japan. Econ. Geol. Monogr., 5:439-487.

Charlou, J.L., Bougault, H., Appriou, P., Nelsen, T., and Rona, P., 1991. Different TDM/ $\mathrm{CH}_{4}$ hydrothermal plume signatures: TAG site at $26^{\circ} \mathrm{N}$ and serpentinized ultrabasic diapir at $15^{\circ} 05^{\prime}$ on the Mid-Atlantic Ridge. Geochim. Cosmochim. Acta, 55:3209-3223.

Delaney, J.R., Mogk, D.W., and Mottl, M.J., 1987. Quartz-cemented sulfidebearing greenstone breccias from the Mid-Atlantic Ridge: samples of a high-temperature hydrothermal upflow zone. J. Geophys. Res., 92:91759192.

Delaney, J.R., Muenow, D.W., and Graham, D.G., 1978. Abundance and distribution of water, carbon, and sulfur in the glassy rims of submarine pillow basalts. Geochim. Cosmochim. Acta, 42:581-594.

Dick, H.J.B., Erzinger, J., Stokking, L.B., et al., 1992. Proc. ODP, Init. Repts., 140: College Station, TX (Ocean Drilling Program).

Dixon, J.E., Stolper, E., and Delaney, J.R., 1988. Infrared spectroscopic measurements of $\mathrm{CO}_{2}$ and $\mathrm{H}_{2} \mathrm{O}$ in Juan de Fuca Ridge basaltic glasses. Earth Planet. Sci. Lett., 90:87-104.

Fehn, U., and Cathles, L., 1986. The influence of plate movement on the evolution of hydrothermal convection cells in the oceanic crust. Tectonophysics, 125:289-312.

Fox, C., 1990. Consequences of phase separation on the distribution of hydrothermal fluids at ASHES vent field, Axial Volcano, Juan de Fuca Ridge. J. Geophys. Res., 95:12923-12926.

Gable, R., Morin, R.H., and Becker, K., 1989. Geothermal state of Hole 504B: ODP Leg 111 overview. In Becker, K., Sakai, H., et al., Proc. ODP, Sci. Results, 111: College Station, TX (Ocean Drilling Program), 87-96.

\footnotetext{
Abbreviations for names of organizations and publications in ODP reference lists follow the style given in Chemical Abstracts Service Source Index (published by American Chemical Society).
} 
Gillis, K.M., and Thompson, G., 1993. Metabasalts from the Mid-Atlantic Ridge: new insights into hydrothermal systems in slow-spreading crust. Contrib. Mineral. Petrol., 113:502-523.

Gillis, K.M., Thompson, G., and Kelley, D.S., in press. A view of the lower crustal component of hydrothermal systems at the Mid-Atlantic Ridge. $J$. Geophys. Res.

Goldfarb, M.S., and Delaney, J.R., 1988. Response of two-phase fluids to fracture configurations within submarine hydrothermal systems. J. Geophys. Res., 93:4585-4594.

Honnorez, J., Alt, J.C., Honnorez-Guerstein, B.-M., Laverne, C., Muehlenbachs, K., Ruiz, J., and Satzman, E., 1985. Stockwork-like sulfide mineralization in young oceanic crust: Deep Sea Drilling Project Hole 504B. In Anderson, R.N., Honnorez, J., et al., Init. Repts. DSDP, 83: Washington (U.S. Govt. Printing Office), 263-282.

Javoy, M., and Pineau, F., 1991. The volatile record of a "popping" rock from the Mid-Atlantic Ridge at $14^{\circ} \mathrm{N}$ : chemical and isotopic composition of gas trapped in the vesicles. Earth Planet. Sci. Lett., 107:598-611.

Kelley, D.S., and Delaney, J.R., 1987. Two-phase separation and fracturing in mid-ocean ridge gabbros at temperatures greater than $700^{\circ} \mathrm{C}$. Earth Planet. Sci. Lett., 83:53-66.

Kelley, D.S., Gillis, K.M., and Thompson, G., in press. Fluid evolution in submarine magma-hydrothermal systems at the Mid-Atlantic Ridge. $J$. Geophys. Res.

Kelley, D.S., Robinson, P.T., and Malpas, J.G., 1992. Processes of brine generation and circulation in the oceanic crust: fluid inclusion evidence from the Troodos ophiolite, Cyprus. J. Geophys. Res., 97:9307-9322.

Lilley, M.D., Baross, J.A., and Gordon, L.I., 1983. Reduced gases and bacteria in hydrothermal fluids: the Galapagos spreading center and $21^{\circ} \mathrm{N}$ East Pacific Rise. In Rona, P.A., Bostrom, K., Laubier, L., and Smith, K.L., Jr. (Eds.), Hydrothermal Processes at Seafloor Spreading Centers: New York (Plenum), 411-447.

Lilley, M.D., Butterfield, D.E., Olson, E.J., Lupton, J.E., Mackos, S.A., and McDuff, R.E., 1993. Anomalous $\mathrm{CH}_{4}$ and $\mathrm{NH}_{4}$ concentrations at an unsedimented mid-ocean ridge hydrothermal system. Nature, 364:45-47.

Liou, J.G., Kuniyoshi, S., and Ito, K., 1974. Experimental studies of the phase relations between greenschist and amphibolite in a basaltic system. Am.J. Sci., 274:613-632.

Lister, C.R.B., 1983. The basic physics of water penetration into hot rock. In Rona, P.A., Bostrom, K., Laubier, L., and Smith, K.L., Jr. (Eds.), Hydrothermal Processes at Seafloor Spreading Centers: New York (Plenum), 141-176.

Moody, J.B., Meyer, D., and Jenkins, J.E., 1983. Experimental characterization of the greenschist/amphibolite boundary in mafic systems. Am. J.Sci., 283:48-92.

Nehlig, P., 1991. Salinity of oceanic hydrothermal fluids: a fluid inclusion study. Earth Planet. Sci. Lett., 102:310-325.

Nehlig, P., and Juteau, T., 1988. Flow porosities, permeabilities and preliminary data on fluid inclusions and fossil thermal gradients in the crustal sequence of the Sumail ophiolite (Oman). Tectonophysics, 151:199-221.
Potter, R.W., II, Babcock, R.S., and Brown, D.L., 1977. A new method for determining the solubility of salts in aqueous solutions at elevated temperatures. J. Res. U.S. Geol. Surv., 5:389-395.

Potter, R.W., II, Clynne, M.A., and Brown, D.L., 1978. Freezing point depression of aqueous sodium chloride solutions. Econ. Geol., 73:284-285.

Richardson, C.J., Cann, J.R., Richards, H.G., and Cowan, J.G., 1987. Metaldepleted root zones of the Troodos ore-forming hydrothermal systems, Cyprus. Earth Planet. Sci. Lett., 84:243-253.

Roedder, E., 1984. Fluid inclusions. Rev. Mineral., Mineral. Soc. Am., 12.

Schiffman, P., Bettison, L.A., and Smith. B.M., 1990. Mineralogy and geochemistry of epidosites from the Solea graben, Troodos ophiolite, Cyprus. In Malpas, J., Panayiotou, A., Moores, E., and Xenophontos, C. (Eds.), Ophiolites: Oceanic Crustal Analogues. Proc. Symp. "Troodos 1987”, Geol. Surv. Dep., Min. Agr. Nat. Resour., Nicosia, Cyprus, 673-684.

Schiffman, P., and Smith, B.M., 1988. Petrology and oxygen isotope geochemistry of a fossil seawater hydrothermal system within the Solea Graben, northern Troodos ophiolite, Cyprus. J. Geophys, Res., 93:4612-4624.

Schops, D., and Herzig, P.M., 1990. Sulfide composition and microthermometry of fluid inclusions in the Leg 111 sheeted dike section of Ocean Drilling Program Hole 504B, Costa Rica Rift. J. Geophys. Res., 95:8405-8418.

Shipboard Scientific Party, 1992. Site 504. In Dick, H.J.B., Erzinger, J., Stokking, L.B., et al., Proc. ODP, Init. Repts., 140: College Station, TX (Ocean Drilling Program), 37-200.

Spear, F.S., 1980. NaSi-CaAl exchange equilibrium between plagioclase and amphibole, an empirical model. Contrib. Mineral. Petrol., 72:33-41.

Vanko, D.A., 1988. Temperature, pressure, and composition of hydrothermal fluids with their bearing on the magnitude of tectonic uplift at mid-ocean ridges, inferred from fluid inclusions in oceanic layer 3 rocks. J. Geophys. Res., 93:4595-4611.

Vanko, D.A., Griffith. J.D., and Erickson, C.L., 1992. Calcium-rich brines and other hydrothermal fluids in fluid inclusions from plutonic rocks, Oceanographer Transform, Mid-Atlantic Ridge. Geochim. Cosmochim. Acta, $56: 35-47$.

Vanko, D.A., and Stakes, D.S., 1991. Fluids in oceanic layer 3: evidence from veined rocks, Hole 735B, Southwest Indian Ridge. In Von Herzen, R.P., Robinson, P.T., et al., Proc. ODP, Sci. Results, 118: College Station, TX (Ocean Drilling Program), 181-218.

Welhan, J.A., 1988. Origins of methane in hydrothermal systems. Chem. Geol., 71:183-198.

Zhang, Y.-G., and Frantz, J.D., 1987. Determination of the homogenization temperatures and densities of supercritical fluids in the system $\mathrm{NaCl}-\mathrm{KCl}$ $\mathrm{CaCl}_{2}-\mathrm{H}_{2} \mathrm{O}$ using synthetic fluid inclusions. Chem. Geol., 64:335-350.

Date of initial receipt: 5 April 1993

Date of acceptance: 27 August 1993

Ms 137/140SR-015 